\title{
Distribution and Microstructure Analysis of Ceramic Particles in the Lead-Free Solder Matrix
}

\author{
Manoj Kumar Pal ( $\nabla$ manojsantosh2002@gmail.com ) \\ University of Miskolc https://orcid.org/0000-0003-2803-7449 \\ Gréta Gergely \\ University of Miskolc \\ Dániel Koncz-Horváth \\ University of Miskolc \\ Zoltán Gácsi \\ University of Miskolc
}

\section{Research Article}

Keywords: Lead-free solder, Morphological mosaic, Skewness, IMCs, Neighbour's particle distance

Posted Date: June 19th, 2020

DOl: https://doi.org/10.21203/rs.3.rs-36424/v1

License: (c) (1) This work is licensed under a Creative Commons Attribution 4.0 International License. Read Full License

Version of Record: A version of this preprint was published at Crystal Research and Technology on October 12th, 2020. See the published version at https://doi.org/10.1002/crat.202000123. 


\section{Abstract}

The Sn-3.0Ag-0.5Cu solder alloy is a prominent candidate for the Pb-free solder, and SAC305 solder is generally employed in today's electronic enterprise. In this study, the formation of intermetallic compounds (Cu6Sn5 and Ag3Sn) at the interface, average neighbour's particle distance, and the morphological mosaic are examined by the addition of $\mathrm{SiC}$ and nickel-coated silicon carbide reinforcements within $\mathrm{Sn}-3.0 \mathrm{Ag}-0.5 \mathrm{Cu}$ solder. Results revealed that the addition of $\mathrm{SiC}$ and $\mathrm{SiC}(\mathrm{Ni})$ particles are associated with a small change to the average neighbor's particle distance and a decrease of clustering rate to a certain limit of the $\mathrm{Sn}-3.0 \mathrm{Ag}-0.5 \mathrm{Cu}$ solder composites. Moreover, the development of the Cu6Sn5 and the structure of the Ag3Sn are improved with the addition of $\mathrm{SiC}$ and $\mathrm{Ni}$ coated SiC.

\section{Introduction:}

Lead-free solder composites, fabrications that combine solder matrices and ceramic reinforcement, for example, $\mathrm{SiC}, \mathrm{TiO}_{2}, \mathrm{Al}_{2} \mathrm{O}_{3}$, and $\mathrm{Si}_{3} \mathrm{~N}_{4}$, have been progressively changed to be used for important structural electronic packaging for commercial industrial applications. They show superior mechanical, thermal, and electrical properties $[1,2]$. The distribution of fine particles is either completed inside the solid or liquid state. The solid-state method is a powder metallurgy method that contains a mixed powder of each essential ingredient. However, the powder metallurgy (PM) method is the most interesting for several reasons. First, powder metallurgy provides morphological phase control. Second, the lower temperatures used in the process mean that the kinetics of the interface is precisely controlled. The regular PM method for making lead-free solder composites include (1) Mixing, where the lead-free solder is mixed with reinforcement particles; (2) compaction by die pressing, and (3) sintering.

A more uniform distribution of ceramic particles can be found if composites are made with powder metallurgy rather than stir casting method [3]. Figure 1a shows a schematic diagram of the reinforcement and matrix powder mixture and Fig. $1 \mathrm{~b}$ shows the homogeneous distribution. It can be a favorable technique for producing various lead-free alloys were such where such problems often occur. But pure lead-free solder powder has a high propensity to agglomerate and stick with the milling jar and balls during milling [4-5]. Such an agglomeration and sticking impact make it very hard to control configuration. However, the problem of agglomeration and adhesion of the powder can be overcome by using process control agents (PCA), such as stearic acid and ethanol [5-6].

The success of lead-free solder alloys is due to the formation of intermetallic compounds (IMC), such as $\mathrm{Cu}_{6} \mathrm{Sn}_{5}$ and $\mathrm{Ag}_{3} \mathrm{Sn}$ in the $\beta$-Sn matrix, which provides mechanical strength. $\mathrm{Cu}_{6} \mathrm{Sn}_{5} \mathrm{IMC}$ is brittle however $\mathrm{Ag}_{3} \mathrm{Sn}$ is ductile [7]. Lehman et al. [8] noted that the mechanical reliability of such alloys depends on the relative orientation and microstructure formation of such IMCs in the $\beta$-Sn matrix. El-Daly et al. [9] were reported that hard SiC and improved IMCs can prevent dislocation and gives a strong dispersion in leadfree solder composites. El-Daly et al. [10] and Tsao [11] were reported that the notable effect of SiC and $\mathrm{TiO}_{2}$ particles on $\mathrm{Pb}$-free solder alloys is to refine the IMCs and the microstructure. 
Particle Size and shape are critical quality and have a huge impact on the overall performance of downstream processes (such as powder treatment) and directly influences the properties of the end products (e.g., uniformity, strength, and stability) $[6,12]$. Numerous off-line tools may be used to evaluate the particle size distribution (PSD) of particles produced during a crystallization technique. In-situ apparatus utilization is of specific significance and Image analysis techniques can be used for evaluating size and shape data of particles dispersed in a composite [13].

Digital image processing was used to estimate the size and size distribution of round particles. The computer-based image processing technique is explored as an opportunity to provide solutions for practical measurement, identification, and analysis of particle distribution. Achieving similar results with a guided approach will be slow and meticulous [14]. After the particles were recognized, various methods of categorization were proposed. Chen et al. [15] have utilized wavelets for picture segmentation and the curvature of the items to distinguish circles. Larsen et al. [16] have used line fitting to concentrate needlelike particles from uproarious pictures.

El Arnaout et al. [17] was managed for uneven (irregular) illumination of the image by rejecting or correcting non-focal particles by rolling background subtraction and sliding paraboloid of rotation. Irregular illumination image was occurred due to objects out of focus, blurriness, and noise which was rejected or corrected. Sarkar et al. [18] and Zhou et al. [19] proposed object filtering methods to moderate partially distinguished objects utilizing morphological highlights and they evaluate the estimations utilizing physically clarified particle masks.

The purpose of this investigation is to develop the $\mathrm{SiC}$ and $\mathrm{SiC}(\mathrm{Ni})$ reinforced $\mathrm{Sn}-3.0 \mathrm{Ag}-0.5 \mathrm{Cu}$ lead-free solder based composites using powder metallurgy technique to examine the microstructure, average neighbour's particle distance and morphological mosaic by the image analysis technique.

\section{Materials And Experimental Procedures:}

The base material, lead-free solder powder (SAC305) with an average particle diameter of 20-28 $\mu \mathrm{m}$, was purchased from Cobar Europe B.V., Breda, Netherlands. The SiC provided by SIKA TECH. Switzerland with a size of $1-3 \mu \mathrm{m}$.

Several trials have shown that ceramic metal contact can be improved with an intermediate nickel coating. Coated ceramics production is reasonable for the PM procedure. SiC particles were coated independently with nickel via an electroless technique $[20,21]$. Table 1 shows the process of Ni-coating on silicon carbide particles. 


\section{Pre-treatment process}

(1) Ultrasonic cleaning using acetone for 20 minutes

(2) Acidic pre-treatment process: clean in $\mathrm{NaH}_{2} \mathrm{PO}_{2} \cdot \mathrm{H}_{2} \mathrm{O}(60 \mathrm{~g} / \mathrm{L})$ and $\mathrm{C}_{3} \mathrm{H}_{6} \mathrm{O}_{3}(2 \mathrm{ml})$ at $85^{0} \mathrm{C}$ for 35 minutes (magnetic steering)

(3) Drying the powder in the furnace at $110^{\circ} \mathrm{C}$.

Nickel coating bath composition

Nickel sulphate

$\mathrm{NiSO}_{4} \cdot 7 \mathrm{H}_{2} \mathrm{O}$

$56 \mathrm{~g} / \mathrm{L}$

Sodium hypophosphite

$\mathrm{NaH}_{2} \mathrm{PO}_{2} \cdot \mathrm{H}_{2} \mathrm{O}$

$60 \mathrm{~g} / \mathrm{L}$

Lactic acid

$\mathrm{C}_{3} \mathrm{H}_{6} \mathrm{O}_{3}$

$2 \mathrm{ml}$

Operating condition: $\mathrm{T}=85^{\circ} \mathrm{C}$, Time $(\mathrm{t})=60$ minutes (magnetic steering), $\mathrm{pH}=6.5$

SAC305 lead-free solder powder is mixed with three different percentages $(0.5,1.0$, and $1.5 \mathrm{wt} . \%)$ with micron-sized $\mathrm{SiC}$ and nickel-coated $\mathrm{SiC}$ by powder metallurgy route. In this examination, the SAC305 powders (average particle size of 20-28 $\mu \mathrm{m}$ ) and silicon carbide (SiC) and nickel-coated silicon carbide (SiC-Ni) powders were used as the preliminary materials. As a first strategy, the powders were mixed by the extents of SAC305-SiC and SAC305- SiC(Ni) $(0.5,1.0$, and $1.5 \mathrm{wt} \%)$ and afterward ball milled for $1 \mathrm{~h}$ with ceramic balls in a ball miller.

The argon gas was used to anticipate conceivable oxidation of the new surfaces of lead-free solder particles. Each solder mixture was compressed at $200 \mathrm{MPa}$ at room temperature in a cylindrical tool of $12 \mathrm{~mm}$ diameter to produce a cylindrical compacted sample by using a single action press. Sintering became performed at $200{ }^{\circ} \mathrm{C}$ for $3 \mathrm{~h}$ under argon atmosphere. The surfaces of sintered samples were ground and polished to expel any irregularity [12].

More than 100 pictures were taken by FIB-SEM (Focus Ion Beam Scanning Electron Microscope) for inspection. The pictures have a brightening view problem, the focal point of convergence of the right is more suitable. In this way, the adaptive automatic segmentation algorithm is chosen. The particles in the segmented binary image are labeled, and the grouping of particles is examined. The Brensen calculation gave the best outcome with 31 pixel window size and 85 threshold value. The particles inside the segmented binary image are labeled, and the clustering of the particles is inspected.

\section{Results And Discussion:}

\subsection{Microstructure of solder composites:}


According to FIB-SEM (Focus Beam Scanning Electron Microscope) examination in Fig. 2a, $\beta$-Sn appears directly across the entire SEM micrograph of the SAC305-SiC and SAC305-SiC(Ni)composite solder. A cross-section view of the micrograph was taken after standard metallographic polishing. Figure 2a shows the primary $\beta-\mathrm{Sn}, \mathrm{SiC}$, and $\mathrm{Ag}_{3} \mathrm{Sn}$ (bright) with irregular $\mathrm{Cu}_{6} \mathrm{Sn}_{5}$ (gray) IMC. The average size of $\mathrm{Ag}_{3} \mathrm{Sn}$ and $\mathrm{Cu}_{6} \mathrm{Sn}_{5}$ IMCs particles were identified as 1-2.5 $\mu \mathrm{m}$ and 2-4 $\mu \mathrm{m}$ in the SAC305-SiC lead-free composite solder. Some pores are established along the SiC surface. The microstructure consists of intermetallic compounds (IMCs) as shown by the arrow in Fig. $2 \mathrm{~b}$ and c, which is scattered inside the $\mathrm{Sn}$ rich matrix.

SiC was coated with nickel because the presence of IMCs in the SAC305-SiC alloy is not sufficient to provide alloy strength. The addition of small amounts of $\mathrm{SiC}(\mathrm{Ni})$ particles in the SAC305 solder alloys shows that the average size of IMCs $\left(\mathrm{Ag}_{3} \mathrm{Sn}\right.$ and $\left.\mathrm{Cu}_{6} \mathrm{Sn}_{5}\right)$ grains were reduced. The reduction of IMCs grains in the composite solders also indicates that the grain refining effect is caused only by the addition of nickel-coated silicon carbide. The average size of $\mathrm{Ag}_{3} \mathrm{Sn}$ and $\mathrm{Cu}_{6} \mathrm{Sn}_{5}$ grains were identified as 0.5$1.5 \mu \mathrm{m}$ and $1-2.5 \mu \mathrm{m}$ in the SAC305-SiC(Ni) lead-free composite solder. Such IMCs are played a key role in the matrix since IMCs provide the strength of the matrix $\beta-S n)$. A high percentage of $\beta-S n$ reduces the modulus of elasticity and yield strength of the lead-free solder composites. However, the existence of IMCs improves the strength and elastic modulus and gives stiffness of the composites [7, 22]. Figure 3 shows the cross-section view FIB-SEM micrograph of SAC305-SiC solder composite which contains IMCs, $\mathrm{SiC}, \beta-\mathrm{Sn}$, cracks, and pore along with the reinforcement.

Similar to SAC305-SiC, the matrix contains primary $\beta$-Sn particles and the IMCs $\left(\mathrm{Ag}_{3} \mathrm{Sn}\right.$ and $\left.\mathrm{Cu}_{6} \mathrm{Sn}_{5}\right)$ were dispersed in the matrix. Figure $4 \mathrm{a}-\mathrm{d}$ demonstrates that the inclusion of a modest quantity of $\mathrm{SiC}(\mathrm{Ni})$ to SAC305 solder alloy could change the microstructure of the SAC305 solder matrix. The distribution of SiC (Ni) particles in the matrix is uniform and the better tendency to be distributed along the boundary of the $\beta$-Sn particles (Fig. 4a). Figure 4a-c additionally demonstrates that the SAC305 solder contains a lot of fine IMC particles. FIB-SEM analysis of $\mathrm{Cu}_{6} \mathrm{Sn}_{5}$ and $\mathrm{Ag}_{3} \mathrm{Sn}$ IMCs shows that size and distribution have changed significantly between SAC305-SiC and SAC305-Si(Ni) composites. It indicates that the weight percentage of reinforcing particles is sufficient to significantly influence on the growth dynamics of $\mathrm{Cu}_{6} \mathrm{Sn}_{5}$ and $\mathrm{Ag}_{3} \mathrm{Sn}$ in nickel-coated silicon carbide composite solder. The comparable phenomenon became also determined by Tsao [11,23], who reported that the eminent impact of $\mathrm{TiO}_{2}$ and $\mathrm{Al}_{2} \mathrm{O}_{3}$ particles on $\mathrm{Pb}$-free solder composite solder to refine the microstructure.

\subsection{Average neighbour's particle distance:}

The average neighbour's particle distance, $d_{m n}$, is characterized as the distance between the center of gravity between one particle and its neighbour's particles. This distance is not proportional to the mean 
free path between the particles and the closest neighbour distance. The distribution of $\mathrm{SiC}$ and $\mathrm{SiC}(\mathrm{Ni})$ particles in the SAC305 matrix are estimated to examine the impact on the matrix. Figure $5 a$ and $b$ demonstrate a schematic outline of estimating the average neighbour's particle distance and average neighbour's particle distance image generated by software (Cprob).

Figure 6. (a) Average neighbour's particle distance of SAC305 solder composites with addition of SiC and $\mathrm{SiC}(\mathrm{Ni})$ (b) Skewness of SAC305 solder composites with addition of for $\mathrm{SiC}$ and $\mathrm{SiC}(\mathrm{Ni}) \mathrm{SiC}$.

$d_{m n}=$ Distance between neighbour's particles

$\mathrm{m}=$ First particle

$\mathrm{n}=$ Neighbour's particle

If the average interparticle distance is high (distribution of the particles inside the matrix is good), the mechanical properties might be affected. Figure $6 \mathrm{~b}$ shows the quadrat analysis of the lead-free solder composites is given as a skewness diagram of the number of $\mathrm{SiC}$ and $\mathrm{SiC}(\mathrm{Ni})$ particles per quadrat, $N_{\mathrm{q}}$. Skewness diagram reveals that the overall shape of the $N_{\mathrm{q}}$ distribution varies significantly with the degree of clustering. Indeed, an increase in the amount of reinforcement particle clusters caused the observed $N_{\mathrm{q}}$ distribution to be-come less symmetric; comparison of the average neighboring particle distances of SiC and $\mathrm{SiC}(\mathrm{Ni})$ with the corresponding $N_{\mathrm{q}}$ distributions in Fig. 6a. Skewness $(\beta)$ indicates the degree of asymmetry in the statistical distribution, which is represented by the equation below [24].

$$
\beta=(q) /[(q-1)(q-2)] \sum\left[\left(N_{q i}-N_{q}^{\text {mean }}\right) /(\sigma)\right]^{3}
$$

Where, $\beta=$ Skewness

$q=$ Total number of quadrats studied,

$N_{\mathrm{q} i}=$ Number of $\mathrm{SiC}$ or $\mathrm{SiC}(\mathrm{Ni})$ particles in the $i^{\text {th }}$ quadrat $(i=1,2, . ., q)$,

$=$ Mean number of $\mathrm{SiC}$ or $\mathrm{SiC}(\mathrm{Ni})$ particles per quadrat, and

$\sigma=$ Standard deviation of the $N_{\mathrm{q}}$ distribution 
According to the skewness diagram (Fig. 6b), an increase in $\beta$ indicates an increase in $\mathrm{SiC}$ and $\mathrm{SiC}(\mathrm{Ni})$ clustering. Figure $6 \mathrm{~b}$ shows the variation in $\beta$ with the weight fraction of $\mathrm{SiC}$ and $\mathrm{SiC}(\mathrm{Ni})$ respectively. The skewness $(\beta)$ ranges are $1.3-0.91$ for $\mathrm{SAC} 305 / \mathrm{SiC}$ and $\mathrm{SAC} 305 / \mathrm{SiC}(\mathrm{Ni})$ is $1.08-0.7$. The skewness range is lower for $\mathrm{SAC} 305 / \mathrm{SiC}(\mathrm{Ni})$ composites than $\mathrm{SAC} 305 / \mathrm{SiC}$, so these outcomes are in great concurrence with the dissemination of reinforcement particles in lead-free solder. The quadrant method is a productive technique for recognizing variations in the distribution of reinforcement particles in MMCs. Furthermore, the results from the quadrat analysis can also be utilized for cluster distributions defined by exact statistical relation. The analysis of clustered distribution is an important factor because it can improve the dispersion of reinforcement particles in the MMCs. In both reinforcements, it is small changes in skewness i.e. impact of $\mathrm{Ni}$ coated $\mathrm{SiC}$ is more than SiC.

\subsection{Morphological analysis:}

A mosaic picture is a segment of the plane. Each class of the segment has a mark. Such a segment is produced, specifically, when utilizing object-oriented image coding. The image is portioned into homogeneous zones. The present examination presents an interpolation method for mosaic pictures. The examination of the size appropriation of the cells from the mosaic can demonstrate the clustering of the items. The segmented binary picture was investigated. Another technique is the examination of the morphological mosaic. Here rises the issue of the characteristic point, and this approach overlooks the form of the object. With a constant dilatation of the objects, the tessellation may be made, which is delicate to the size and the state of the object. This technique is the morphological mosaic technique. The investigation of the size carrying of the cell from the mosaic can show the clustering of the objects.

- FIB-SEM micrographs are taken from the polished samples of the inspected tests of SAC305+ $\mathrm{SiC} / \mathrm{SiC}(\mathrm{Ni})$. SiC particles in the blue form are visible in the micrograph. In Fig. 7a and b, the distribution of the SiC particles are in cells. It can be seen as larger and smaller cells in the mosaic structure. In this manner, the size (region) dissemination of the cells is considered. Therefore, the size (area) distribution of the cells is studied. A larger effect can be seen in the SAC305/SiC(Ni) solder composite (Fig. 8a). Figure 8a shows the average cell area of both composites and the cell area of $\mathrm{Ni}$ coated $\mathrm{SiC}$ composite is increased at different weight fractions i.e. particles are uniformly distributed. Figure $8 \mathrm{~b}$ shows the skewness variation of both composites and $\mathrm{SiC}(\mathrm{Ni})$ reinforced composite skewness is much lower than $\mathrm{SiC}$ composites i.e. Ni is very effective in the distribution of the particles in the SAC305 solder matrix.

\section{Conclusions}

This current study investigates the impact of small quantity SiC and nickel-coated SiC microparticles addition on microstructure, average neighbour's particle distance, and morphological mosaic behaviors of Pb-free Sn-3.0Ag-0.5Cu alloy. SAC305-SiC solder composite form larger IMCs ( $\left.\mathrm{Cu}_{6} \mathrm{Sn}_{5} \& \mathrm{Ag}_{3} \mathrm{Sn}\right)$ compared to SAC305-SiC(Ni) composites. Experimental results disclose that nickel-coated $\mathrm{SiC}$ particles 
have significantly refined the microstructure of lead-free SAC305 solder composites. The $\mathrm{SiC}$ and $\mathrm{SiC}(\mathrm{Ni})$ are perfectly distributed in the SAC305 solder matrix however $\mathrm{SiC}(\mathrm{Ni})$ is more homogenous than $\mathrm{SiC}$ in the SAC305 matrix. The morphological mosaic gives the best description of the clustering analysis. Clustering is decreased in $\mathrm{Ni}$ coated $\mathrm{SiC}(\mathrm{Ni})$ reinforced lead-free solder composites.

\section{Declarations}

\section{Acknowledgments:}

The described article was carried out as part of the GINOP-2.3.2-15-2016-00027 "Sustainable operation of the workshop of excellence for the research and development of crystalline and amorphous nanostructured materials" project implemented in the framework of the Szechenyi 2020 program. The realization of this project is supported by the European Union.

\section{References}

1. Arik H (2008) Effect of mechanical alloying process on mechanical properties of a-Si3N4 reinforced aluminum-based composite materials. Mater Des 29:1856-1861. doi:https://doi.org/10.1016/j.matdes.2008.03.010

2. Pal MK, Gergely G, Koncz-Horvath D, Gacsi Z (2018) Investigating the Microstructural and Mechanical Properties of Pure Lead-Free Soldering Materials (SAC305 \& SAC405). Metall Mater Eng 24(1):27-36. doi:https://doi.org/10.30544/344

3. Liu P, Yao P, Liu J (2008) Effect of SiC nanoparticle additions on microstructure and microhardness of Sn-Ag-Cu solder alloy. J Electron Mater 37(6):874-879. doi:https://doi.org/10.1007/s11664-0070366-3

4. El-Daly AA, Desoky WM, Elmosalami TA, El-Shaarawy MG, Abdraboh AM (2015) Microstructural modifications and properties of SiC nanoparticles-reinforced Sn-3.0Ag-0.5Cu solder alloy. Mater Des 65:1196-1204. doi:https://doi.org/10.1016/j.matdes.2014.08.058

5. Fathian Z, Maleki A, Niroumand B (2017) Synthesis and characterization of ceramic nanoparticles reinforced lead-free solder. Ceram Int 43:5302-5310. doi:https://doi.org/10.1016/j.ceramint.2017.01.067

6. Sharma B, Vajpai SK, Ameyama K (2015) Microstructure and properties of beta Ti-Nb alloy prepared by powder metallurgy route using titanium hydride powder. J Alloys Compd 656:978-986. doi:https://doi.org/10.1016/j.jallcom.2015.10.053

7. Basak A, Pramanik A, Riazi H, Silakhori M, Netting A (2018) Failure mechanisms of nanoparticle reinforced metal matrix composite. J Compos Sci 2(2):28. doi:https://doi.org/10.3390/jcs2020028

8. Athavale LehmanLP, Fullem SN, Giamis TZ, Kinyanjui AC, Lowenstein RK, Mather M, Patel K, Rae R, Wang D, Xing J, Zavalij Y, Borgesen L, Cotts P (2004) E.J, Growth of Sn and intermetallic compounds in Sn-Ag-Cu solder. J Electron Mater 33:1429-1439. doi:https://doi.org/10.1007/s11664-004-0083-0 
9. El-Daly AA, Fawzy A, Mansour SF, Younis MJ (2013) Thermal analysis and mechanical properties of Sn-1.0Ag-0.5Cu solder alloy after modification with SiC nano-sized particles. J Mater Sci: Mater Electron 24(8):2976-2988. doi:https://doi.org/10.1007/s10854-013-1200-8

10. El-Daly AA, Al-Ganainy GS, Fawzy A, Younis MJ (2014) Structural characterization and creep resistance of nano-silicon carbide reinforced Sn-1.0Ag-0.5Cu lead-free solder alloy. Mater Des 55:837-845. doi:https://doi.org/10.1016/j.matdes.2013.10.043

11. Tsao LC, Chang SY (2010) Effects of Nano-TiO2 additions on thermal analysis, microstructure and tensile properties of Sn-3.5Ag-0.25Cu solder. Mater Des 31(2):990-993. doi:https://doi.org/10.1016/j.matdes.2009.08.008

12. Pal MK, Gergely G, Koncz-Horvath D, Gacsi Z (2019) Influence of ceramic particles on the microstructure and mechanical properties of SAC305 lead-free soldering material. Arch Metall Mater 64:603-606. doi:10.24425/amm.2019.127585

13. Agimelen OS, Jawor-Baczynska A, McGinty J, Dziewierz J, Tachtatzis C, Cleary A, Haley I, Michie C, Andonovic I, Sefcik J, Mulholland AJ (2016) Integration of in situ imaging and chord length distribution measurements for estimation of particle size and shape. Chem Eng Sci 144:87-100. doi:https://doi.org/10.1016/j.ces.2016.01.007

14. Cardona J, Ferreira C, McGinty J, Hamilton A, Agimelen OS, Cleary A, Atkinson R, Michie C, Marshall S, Chen YC, Sefcik J (2018) Image analysis framework with focus evaluation for in situ characterisation of particle size and shape attributes. Chem Eng Sci 191:208-231. doi:https://doi.org/10.1016/j.ces.2018.06.067

15. Chen J, Wang XZ (2005) A wavelet method for analysis of droplet and particle images for monitoring heterogeneous processes. Chem Eng Commun 192:499-515. doi:https://doi.org/10.1080/00986440590477908

16. Larsen PA, Rawlings JB, Ferrier NJ (2006) An algorithm for analyzing noisy, in situ images of highaspect-ratio crystals to monitor particle size distribution. Chem Eng Sci 61:5236-5248. doi:https://doi.org/10.1016/j.ces.2006.03.035

17. El-Arnaout T, Cullen PJ, Sullivan C (2016) A novel backlight fiber optical probe and image algorithms for real time size-shape analysis during crystallization. Chem Eng Sci 149:42-50. doi:https://doi.org/10.1016/j.ces.2016.04.025

18. Sarkar D, Doan XT, Ying Z, Srinivasan R (2009) In situ particle size estimation for crystallization processes by multivariate image analysis. Chem Eng Sci 64:9-19. doi:https://doi.org/10.1016/j.ces.2008.09.007

19. Zhou Y, Lakshminarayanan S, Srinivasan R (2011) Optimization of image processing parameters for large sets of in-process video microscopy images acquired from batch crystallization processes: Integration of uniform design and simplex search. Chemom Intell Lab Syst 107(2):290-302. doi:https://doi.org/10.1016/j.chemolab.2011.04.014

20. Kretz F, Gácsi Z, Kovács J, Pieczonka T (2004) The electroless deposition of nickel on SiC particles for aluminum matrix composites, Surf. Coatings Technol 180:575-579. 
doi:https://doi.org/10.1016/j.surfcoat.2003.10.150

21. Pal MK, Gergely G, Koncz-Horvath D, Gacsi Z (2020) Investigation of the Electroless Nickel Plated Sic Particles in SAC305 Solder Matrix, Powder Metall. Met Ceram 58(9-10):529-537. doi:https://doi.org/10.1007/s11106-020-00107-y

22. El-Daly AA, Fawzy A, Mansour SF, Younis MJ (2013) Novel SiC nanoparticles-containing Sn-1.0Ag0.5Cu solder with good drop impact performance. Mater Sci Eng A 578:62-71. doi:https://doi.org/10.1016/j.msea.2013.04.022

23. Tsao LC, Chang SY, Lee $\mathrm{Cl}$, Sun $\mathrm{WH}$, Huang $\mathrm{CH}$ (2010) Effects of nano- $\mathrm{Al}_{2} \mathrm{O}_{3}$ additions on microstructure development and hardness of Sn3.5Ag0.5Cu solder. Mater Des 31(10):4831-4835. doi:https://doi.org/10.1016/j.matdes.2010.04.033

24. Karnezis PA, Durrant G, Cantor B (1998) Characterization of reinforcement distribution in cast Alalloy/SiC composites. Mater Charec 40(2):97-109. doi:https://doi.org/10.1016/S10445803(97)00106-X

25. Igathinathane C, Pordesimo LO, Columbus EP, Batchelor WD, Methuku SR (2008) Shape identification and particles size distribution from basic shape parameters using ImageJ. Comput Electron Agric 63:168-182. doi:https://doi.org/10.1016/j.compag.2008.02.007

\section{List of Captions}

\section{Tables}

Table 1 Process of nickel coating on silicon carbide

\section{Pre-treatment process}

(1) Ultrasonic cleaning using acetone for 20 minutes

(2) Acidic pre-treatment process: clean in $\mathrm{NaH}_{2} \mathrm{PO}_{2} \cdot \mathrm{H}_{2} \mathrm{O}(60 \mathrm{~g} / \mathrm{L})$ and $\mathrm{C}_{3} \mathrm{H}_{6} \mathrm{O}_{3}(2 \mathrm{ml})$ at $85{ }^{0} \mathrm{C}$ for 35 minutes (magnetic steering)

(3) Drying the powder in the furnace at $110^{\circ} \mathrm{C}$.

Nickel coating bath composition

Nickel sulphate

Sodium hypophosphite

Lactic acid

Operating condition: $\mathrm{T}=85^{\circ} \mathrm{C}$, Time $(\mathrm{t})=60$ minutes (magnetic steering), $\mathrm{pH}=6.5$

$\begin{array}{ll}\mathrm{NiSO}_{4} \cdot 7 \mathrm{H}_{2} \mathrm{O} & 56 \mathrm{~g} / \mathrm{L} \\ \mathrm{NaH}_{2} \mathrm{PO}_{2} \cdot \mathrm{H}_{2} \mathrm{O} & 60 \mathrm{~g} / \mathrm{L} \\ \mathrm{C}_{3} \mathrm{H}_{6} \mathrm{O}_{3} & 2 \mathrm{ml}\end{array}$

Figures 


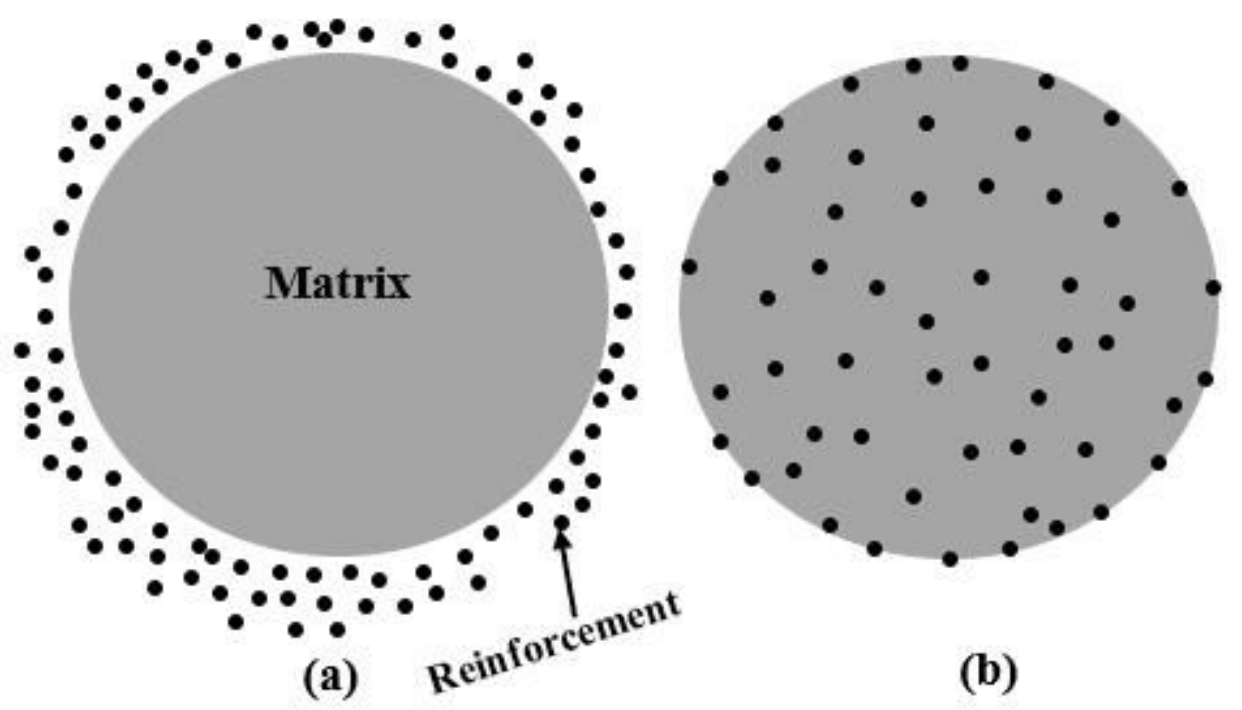

Figure 1

Schematic diagram of reinforcement and matrix powder (modified): (a) before milling (zero-hour milling) and (b) after milling (homogeneous distribution). Adapted from Ref. [5]. 


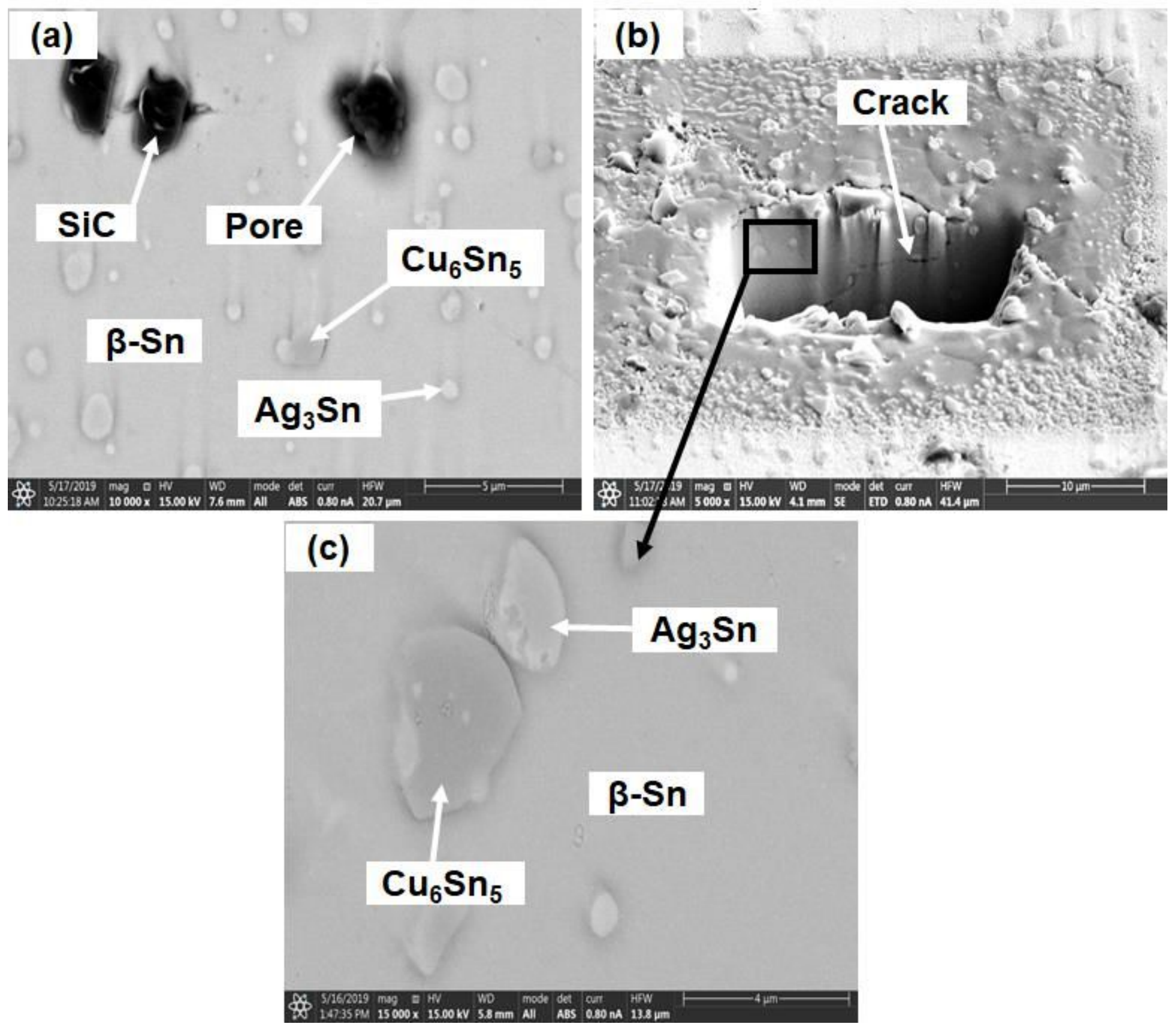

Figure 2

Sn-3.0Ag-0.5Cu solder alloy reinforced with SiC particles: (a) top-view SEM micrograph; (b) cross-section view SEM micrograph; (c) zoom-in view of the area marked in (b). 


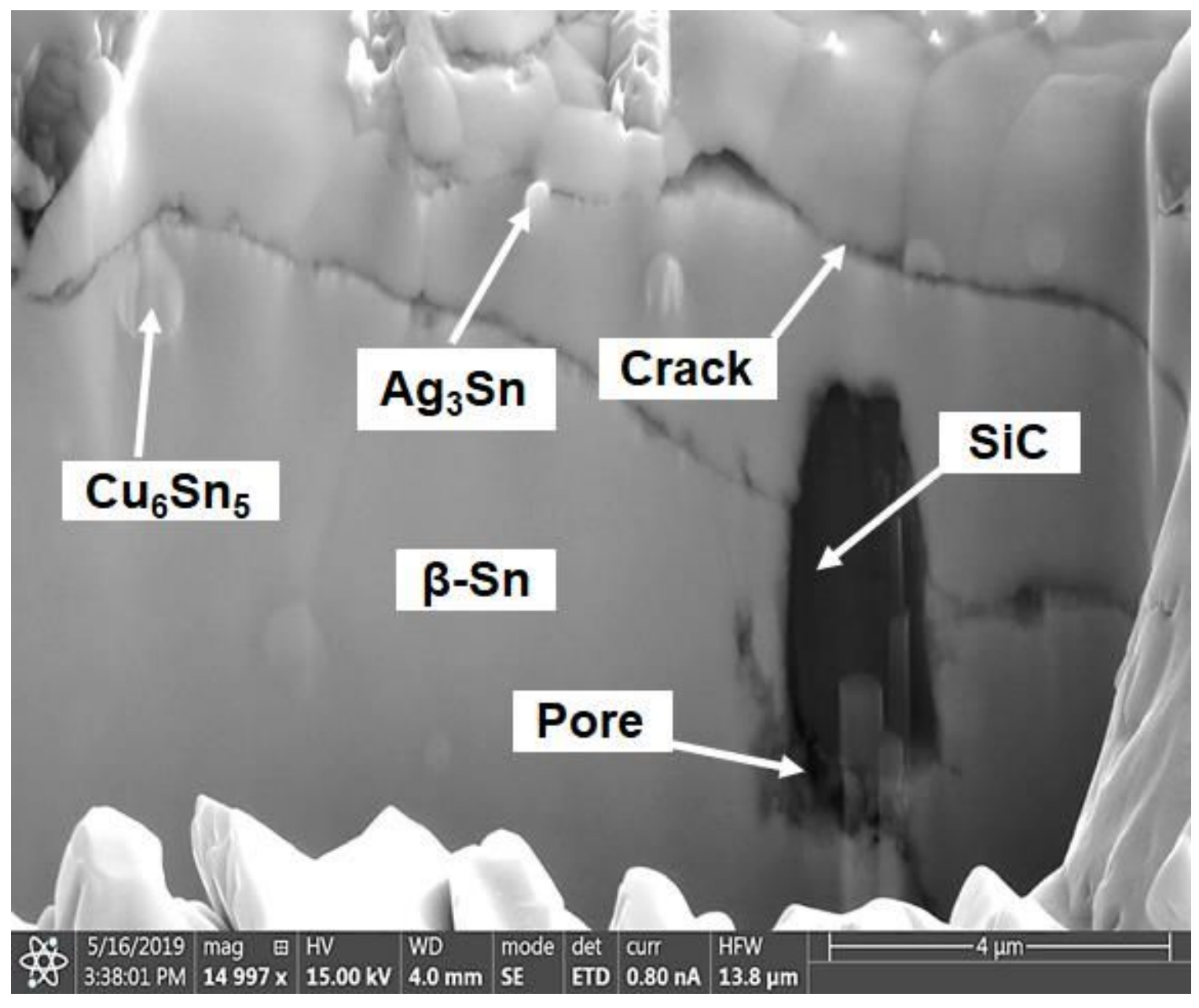

Figure 3

Cross-section view FIB-SEM micrograph of SAC305-1\%SiC solder composite. 

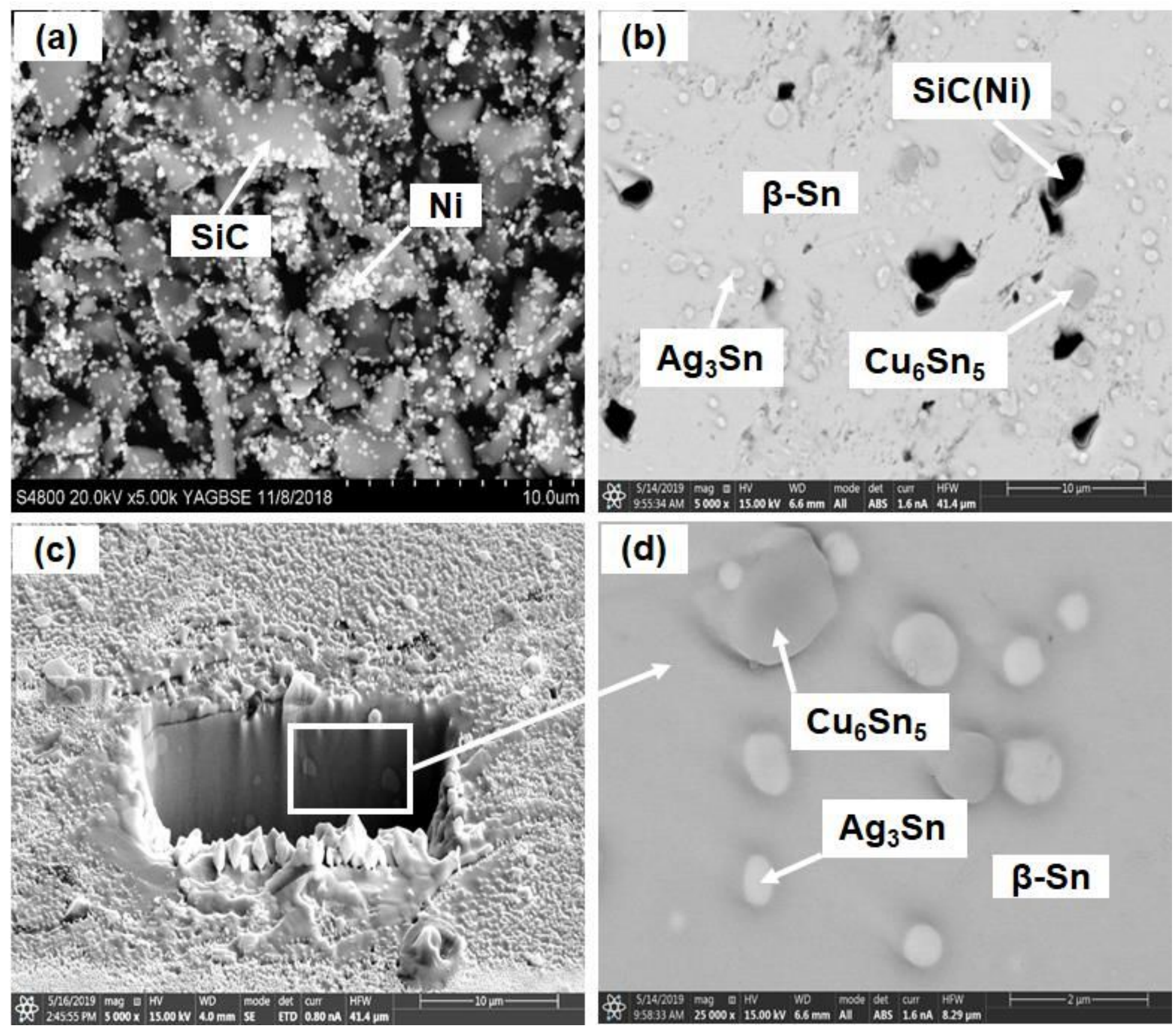

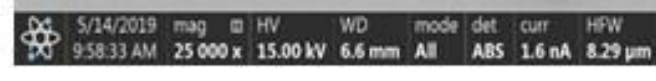

\section{Figure 4}

Sn-3.0Ag-0.5Cu solder alloy reinforced with $\mathrm{SiC}(\mathrm{Ni})$ particle: (a) SEM micrograph of Ni coated SiC (b) Sn3.0Ag-0.5Cu solder alloy reinforced with $\mathrm{SiC}(\mathrm{Ni})$ particles: top-view of SEM micrograph; (c) cross-section view of SEM micrograph; (d) zoom-in view of the area marked in (c). 


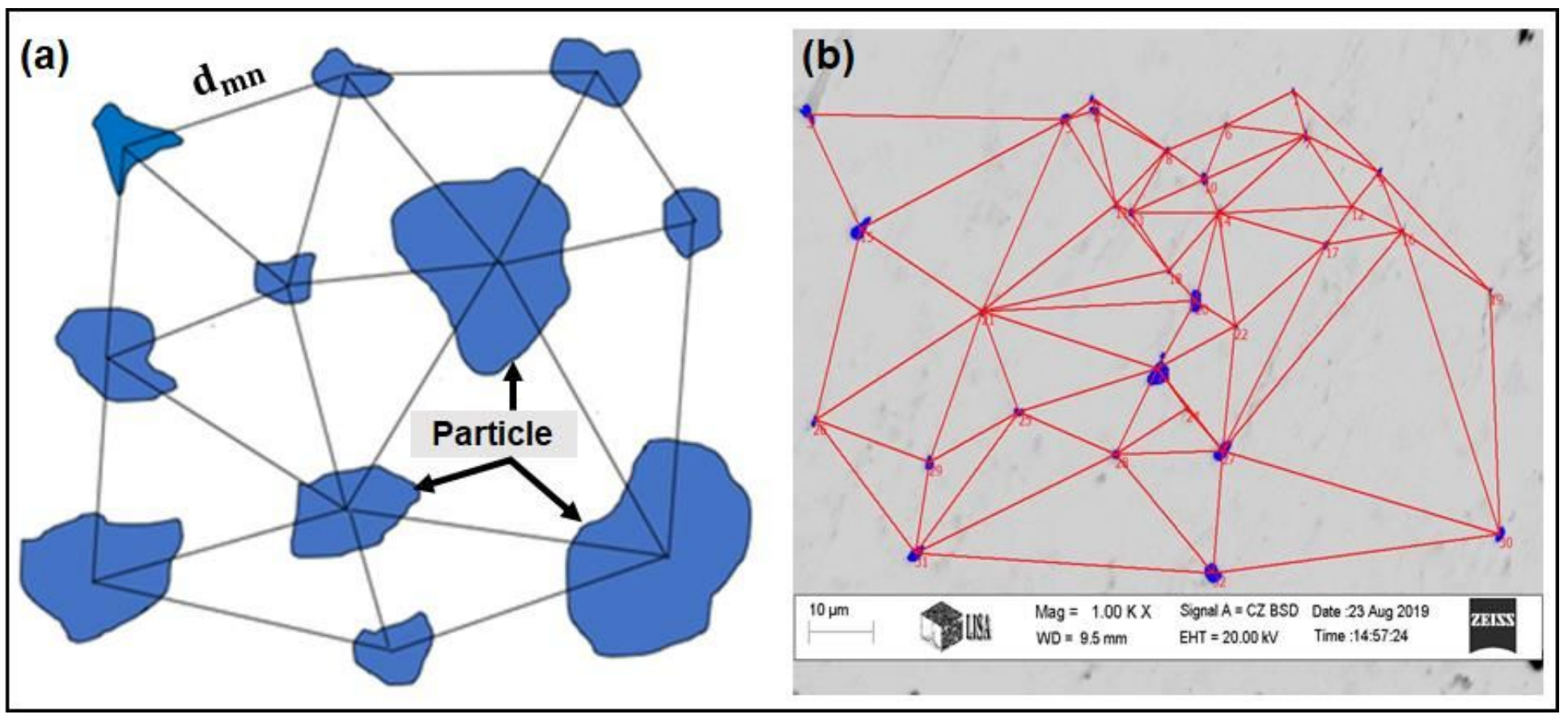

Figure 5

(a) Schematic diagram of neighbour's particles distance (b) Average neighbour's particles distance image generated by software (Cprob).
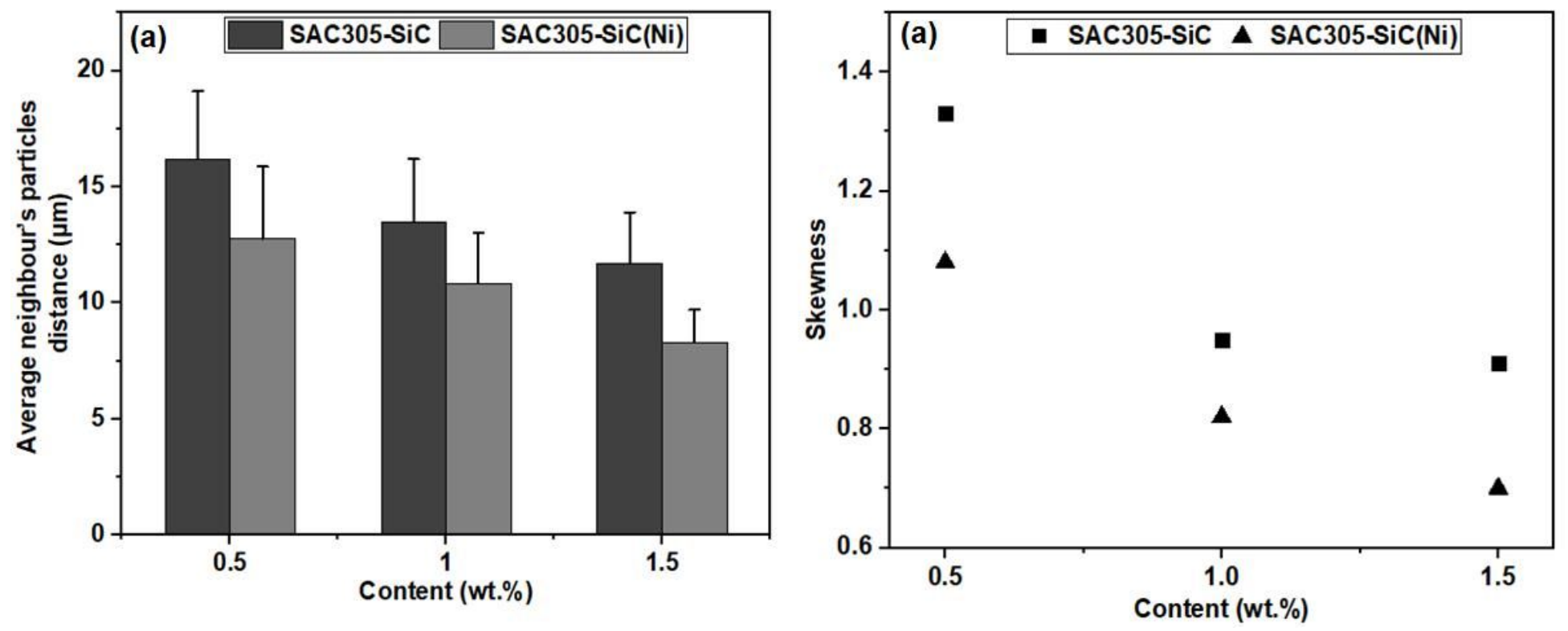

Figure 6

(a) Average neighbour's particle distance of SAC305 solder composites with addition of for SiC and $\mathrm{SiC}(\mathrm{Ni})(\mathrm{b})$ Skewness of SAC305 solder composites with addition of for $\mathrm{SiC}$ and $\mathrm{SiC}(\mathrm{Ni}) \mathrm{SiC}$. 

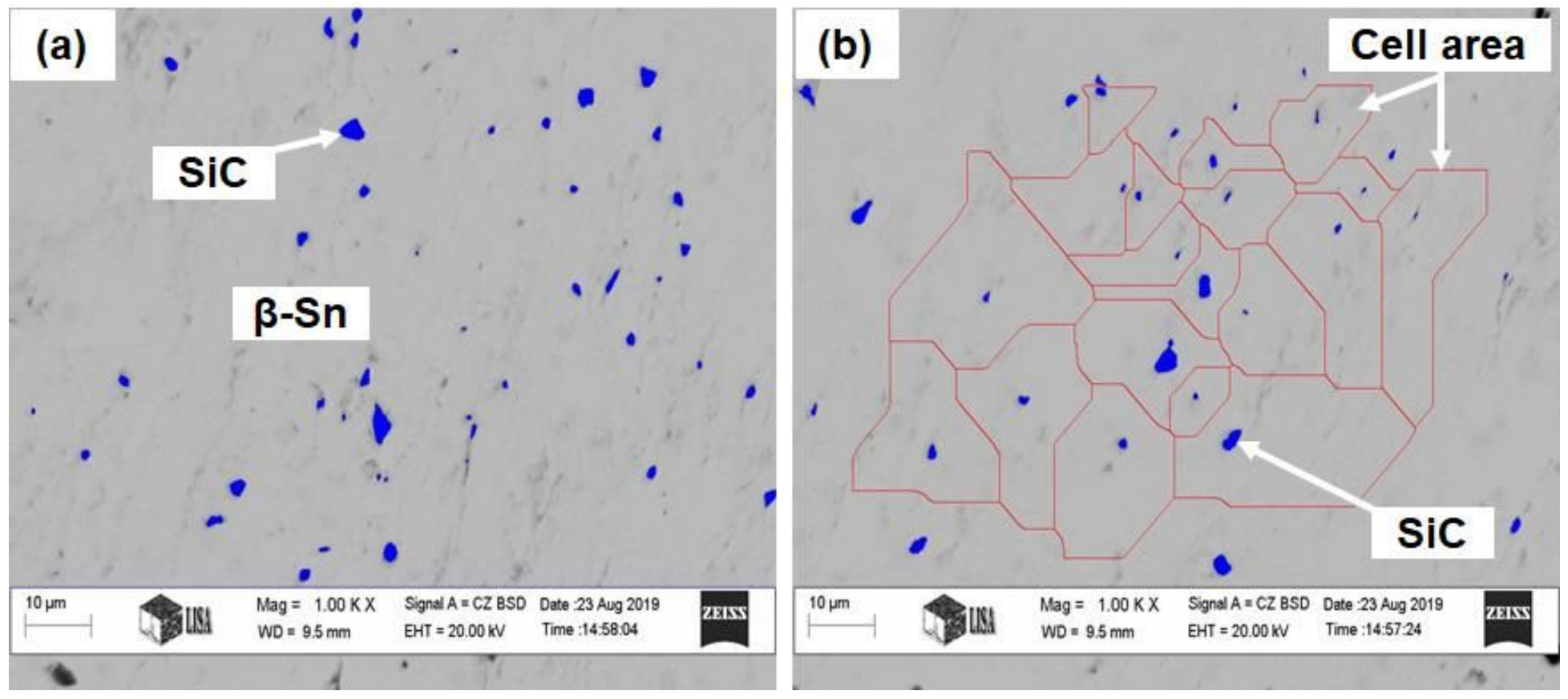

Figure 7

(a) Analysed segmented SEM micrograph of SAC305 solder with addition of SiC (b) Morphological mosaic of the image.
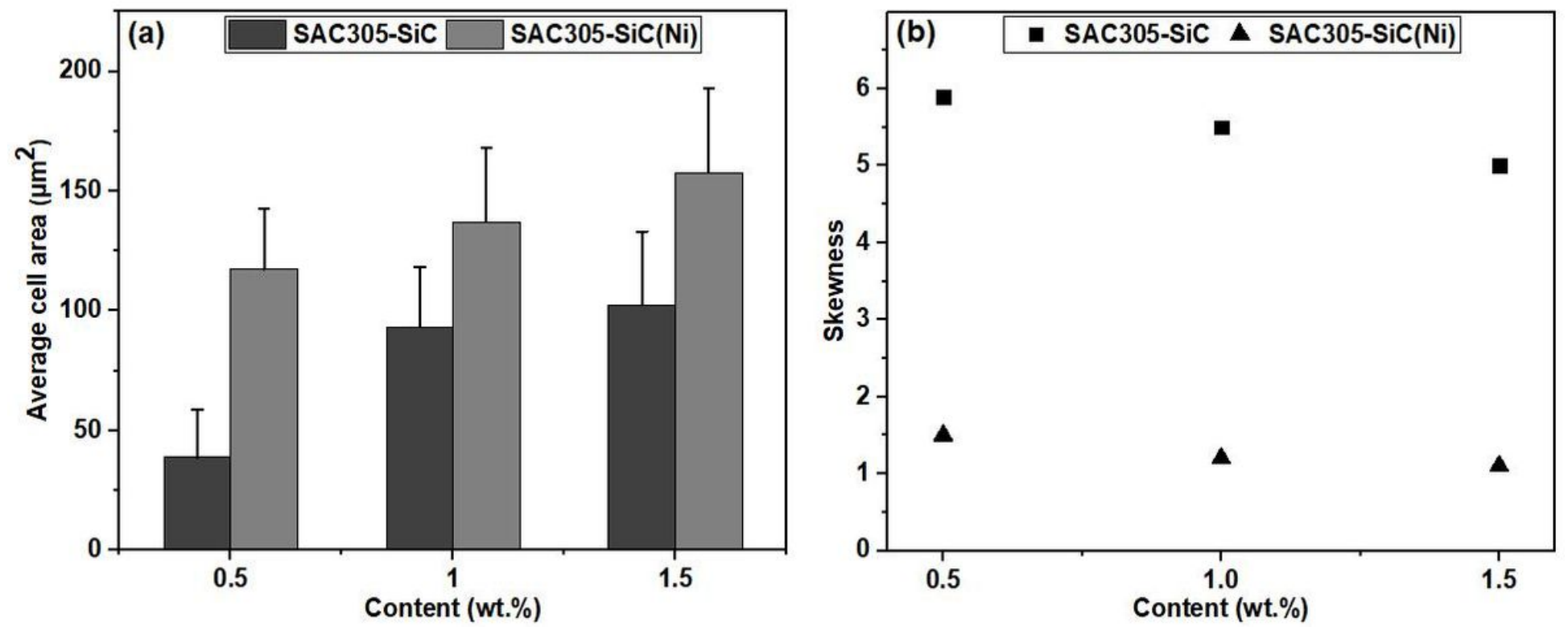

Figure 8

(a) The average cell area of SAC305 solder composites with addition of $\mathrm{SiC}$ and $\mathrm{SiC}(\mathrm{Ni})$ (b) Skewness of SAC305 solder composites with addition of different weight fraction of $\mathrm{SiC}$ and $\mathrm{SiC}(\mathrm{Ni})$. 